\title{
THE USE OF AUTHENTIC MATERIAL IN TEACHING WRITING DESCRIPTIVE TEXT
}

\author{
Gusti Panji Sundana \\ Department of English Education, School of Teacher Training and Education (STKIP) Pasundan Cimahi, \\ Indonesia \\ E-mail: gp_gusti@yahoo.co.id
}

APA Citation: Sundana, G. P. (2017). The use of authentic material in teaching writing descriptive text. English Review: Journal of English Education, 6(1), 81-88. DOI: 10.25134/erjee.v6i1.773.

Received: 19-08-2017

Accepted: 28-10-2017

Published: 01-12-2017

\begin{abstract}
This study was conducted to figure out the effectiveness of using authentic materials in teaching writing descriptive text. The study was carried out at one of private universities in Bandung. This study used authentic materials from magazine, newspaper and internet articles as teaching media. The reason of using authentic materials taken from magazine, newspaper and internet was that they could bring the students into a non-threatening atmosphere in the classroom and link the classroom environment with the real world (Clark, 2000). In this study, the qualitative and quantitative methods were applied to gather the data. The data of this study were collected through pretests, posttest, and questionnaires. The findings indicated that using authentic materials in teaching descriptive writing had a significant role in improving students' writing skill with the significance of 0.05 ( $\alpha$ 0.05). The result of t-obs was 3.218 and $t$-crit was 2.042 . This result was supported by the questionnaire results in which the participants showed positive opinions in learning descriptive writing using authentic materials. Finally, it is expected that this study will give beneficial contribution to the teaching of writing for college students in which the technique applied is recommended to be used as an appropriate alternative to improve students' writing competence.
\end{abstract}

Keywords: descriptive writing, authentic materials

\section{INTRODUCTION}

Writing is one of the two productive skills in learning English that comes after speaking. As a productive skill, many private college students struggle a lot to master English writing skill. Some research findings have indicated that the students' writing ability is yet far from satisfaction. Katilie (2003) carried out a study of why the students had a poor quality in English writing composition. She found that the reason why the students achieved unpleasant result in writing English composition was because the practices of inappropriate teaching strategy in the class. This is supported by Alwasilah (2007) who asserted that writing is complicated for students. Furthermore, he added that in the classroom activities, writing is considered as the hardest skill.

Writing skill in English as a foreign language is apparently not easy (Gibbons, 2002 , p. 52) but it doesn't mean it is impossible to be taught. This statement is supported by Feez and Joyce (2000, p. 1) who stated that writing is the ability of creating written texts and that everyone can be taught this technique if they are supported with the correct tools.

Alwasilah (2000, p. 12) pointed out that teachers are likely to teach students topic on spelling, word formation, vocabulary, grammar and theories of writing and consequently ignoring the practice of writing. In line with what had been stated by Alwasilah, the researcher observes that in the present teaching and learning process, writing activities are mostly dominated by arranging jumbled words to be a sentence or jumbled sentences to be a paragraph and completing a dialogue or a passage. The students are also requested to write a simple paragraph using their own words without their teacher's assistance, very often, they face the problem 
of finding the ideas to write. As a result, it is difficult for the students to express their ideas on paper.

Based on that condition, the researcher strives to reduce those burdens by conducting a study employing a kind of teaching technique and materials that can help students generate their ideas. Regarding the availability of teaching materials, providing interesting and authentic materials for language teaching is not a big problem anymore. The teachers can find the necessary material for teaching everywhere and every time through the internet, newspapers, and magazine. Gilmore (2007, p. 98) cited in (Syafri 2011, p. 1) stated that authentic materials offer resources for the English teachers to expose the students into a real language resource of the actual speakers and writers. In line with this, Yusuf and Tanti (2010) found that authentic materials benefit both teachers and students. They inspired teachers to improve their skills in developing materials and activities for the students. While for the students, they attracted their attention and drove their attention in learning. In addition, Berardo (2006) shared his personal experience in teaching using authentic materials. He observed that the students experienced great exposure of real language used in real context. He found the authentic material interesting and more up to date than the textbooks. The outcome of Berardo's research is also in line with the research conducted by Rojas (2012). Despite those studies have shown how useful authentic materials are, however, they have not yet been implemented in teaching writing descriptive text. Therefore, this study investigates the use of authentic material in improving students' ability in writing descriptive paragraphs.

\section{METHOD}

In order to obtain comprehensible description of the effect of authentic materials to descriptive writing, pre-test and post-test were occupied in the study, while to validate the attitudes towards the use of authentic materials, questionnaire was employed. The pre-test was conducted in the first meeting to see the initial writing skill of the students and the post-test was arranged in the last meeting to figure out the achievement gained by the students after the treatment.

The material for the pre-test and post-test were actually the same so that the researcher can assess the progress of students' ability in writing descriptive paragraph. The scoring system employed was based on Heaton (1988) in which the aspects assessed involving grammar, vocabulary, mechanism, and content.

A week after the pre-test, the students of experimental class was assigned to write a descriptive paragraph based on material given to them. The material about best friends was taken from the internet (http://www.booksie.com), the material for describing famous places was taken from $C N N$ Traveler Magazine (May-June Edition 2011), the material for describing about favorite movies was taken from the internet (http://www.imdb.com), and for the last meeting, the students were demanded to describe about their favorite movies in which the article was taken from Reader's Digest Magazine (November 2010 edition). The students in control class were also asked to write a descriptive paragraph of famous person, famous places, favorite movies, and favorite actors and actresses.

After gathering the data, the post-test was given to both classes. As mentioned beforehand, the test employed in the post-test was similar to the pre-test. The post-test score of both classes were, later, compared to figure out the influence of the use of authentic material in teaching learning process. Further, to obtain more accurate data, the questionnaire was handed out to experimental class to investigate students' attitudes towards the use of authentic materials. The questionnaire was also handed out to the control class students in order to measure their attitudes towards the use of non-authentic materials in teaching descriptive paragraph. The students were assigned to choose the alternative answer by marking 1 for strongly disagree, 2 for disagree, 3 for neither agree nor disagree, 4 for agree, and 5 for strongly agree. The questionnaire was planned to find out whether the use of authentic materials could assist students to improve their writing or not. 


\section{RESULTS AND DISCUSSION}

Results and discussion section explains the variations among the test result to figure out the effect of authentic materials used in descriptive writing. Meanwhile, the data of questionnaire endeavor to figure out the students' attitudes towards the use of authentic materials in teaching descriptive paragraph through collaborative work.

\section{T-test statistical measurement}

In order to find out whether the initial skill of experimental and control class is in the same level, the students' pretest score of both experimental and control class was analyzed and estimated by using independent t-test through statistical product and solution (SPSS), and the result is illustrated in the table below.

\begin{tabular}{|c|c|c|c|c|c|c|c|}
\hline & $\mathbf{N}$ & $\begin{array}{l}\text { Mean } \\
\text { Difference }\end{array}$ & $\begin{array}{l}\text { Std. error } \\
\text { difference }\end{array}$ & T obs & Df & t table & $\begin{array}{l}\text { Sig. (2- } \\
\text { tailed) }\end{array}$ \\
\hline $\begin{array}{l}\text { Exp. and } \\
\text { Control Pre-test }\end{array}$ & 32 & 1.00000 & 5.26936 & .190 & 30 & 2.042 & .851 \\
\hline
\end{tabular}

Afterward, the result of independent t-test computation analysis showed that the independent samples mean achieved 1.00000, standard error difference was 5.26936, tobs was .190, in which the degree of t table was at the significant level $(\alpha=0.05)$ with the $d f 30$ was 2.042. It was discovered that the $\mathrm{t} o b s$ was lower than $\mathrm{t}$ table ( $\mathrm{t}$ test $<\mathrm{t}$ table), therefore, the null hypothesis was supported. It displayed that there was no significant difference between the means of pretest scores for both experiment and control class. Therefore, it can be concluded that the two classes belong to the same population. This circumstance signified that the procedure of teaching descriptive paragraph using authentic materials can be implemented in experimental class.

Furthermore, as same as pretest data, the data from posttest were analyzed and then compared by using t-test independent sample test. It is done to see the dissimilarity of students' achievement on writing ability between the experimental class (treated by using authentic materials) and the control class (treated by using non authentic materials). The result of independent sample test in post-test can be seen in Table 2 .

Table 2. Independent sample test of post-test of experimental and control classes

\begin{tabular}{lccccccc}
\hline & N & $\begin{array}{l}\text { Mean } \\
\text { Difference }\end{array}$ & $\begin{array}{l}\text { Std. error } \\
\text { difference }\end{array}$ & T obs & Df & t table & $\begin{array}{l}\text { Sig. (2- } \\
\text { tailed) }\end{array}$ \\
\hline $\begin{array}{l}\text { Exp. and } \\
\text { Control Pre-test }\end{array}$ & 32 & 14.93750 & 4.64251 & 3.218 & 30 & 2.042 & .003 \\
\hline
\end{tabular}

Having calculated the data using the independent t-test computation, the mean difference of both classes was 14.93750, the standard error difference was 4.64251, and the value of $\mathrm{t} o b s$ was 3.218. It also displayed that the t table of at a significant level $(\alpha=0.05)$ with the degree of freedom 30 was 2.042 and the significance (2 tailed) was .003 .

On the strength of the computation in the table above, the outcome of $\mathrm{t} o b s$ was 3.218, while the score of table was at significant level $(\alpha=0.05)$ with the degree of freedom was 2.042. It could be confirmed that the tobs is higher than $\mathrm{t}$ table ( $\mathrm{t}$ test $>\mathrm{t}$ table). It indicated that the null hypothesis is rejected.
Therefore, it signified that the experimental students belong to different population. In other word, the treatment of authentic materials in descriptive writing confirmed that the achievement of experimental class was significantly different from the accomplishment of the control class.

\section{Hypothesis testing}

The reason of the hypothesis testing in this study is to figure out the stage of effectiveness of the treatment presented to the experimental class matching up to the control class. The hypothesis testing is carried out making comparative analysis method for the 
four scores gained from the two sample classes.

\section{Comparative analysis of pre-test and posttest of the experimental class}

The purpose of this hypothesis testing in this part is to figure out whether there is a significance difference between the pretest and the posttest scores in the experimental class. The hypothesis can be spotted below:

$$
\mathrm{H}_{0}: \mu 1=\mu 2
$$

There is no significance difference between the means of pretest and posttest scores.

$\mathrm{H}_{\mathrm{i}} \quad: \mu 1 \neq \mu 2$

The mean of posttest score is higher than pretest one.

The two hypotheses above were tested by using test of statistic-t: t-test of Paired Two Sample of Means. The criteria of testing are: $\mathrm{H}_{0}:$ Accepted if t-Stat $<\mathrm{t}$-Crit. $: \mu 1=\mu 2$ $\mathrm{H}_{0}:$ Rejected if t-Stat $\geq \mathrm{t}$-Crit. $: \mu 1>\mu 2$

Grounded on the statistical calculation of the pretest and posttest of the experimental class with the level of significance 0.05 and the degree of freedom 15, it was discovered that the value of t-Stat was 11.726. Since the value of t-Crit at the degree of freedom 15 was 2.132. It means the value of $t-S t a t$ was higher than t-Crit. Therefore it could be confirmed that there is a significant difference between pretest and posttest in the experimental class in which the posttest is higher than the pretest score.

2. Comparative analysis of the pretest and posttest scores of the control class

The purpose of testing hypothesis in this part is also to figure out the significant difference between the pretest and posttest of control class. Below is the used hypothesis:

$$
\mathrm{H}_{0}: \mu 1=\mu 2
$$

There is no significance difference between the means of pretest and posttest scores.

$$
\mathrm{H}_{\mathrm{i}} \quad: \mu 1 \neq \mu 2
$$

The mean of posttest score is higher than pretest one.

The two hypotheses above were tested by using test of statistic-t: t-test of Paired Two Sample of Means. The criteria of testing are: $\mathrm{H}_{0}:$ Accepted if $\mathrm{t}-$ Stat $<\mathrm{t}$-Crit. $: \mu 1=\mu 2$ $\mathrm{H}_{0}:$ Rejected if t-Stat $\geq \mathrm{t}$-Crit. $: \mu 1>\mu 2$

Grounded on the statistical calculation with the level significance of 0.05 and the degree of freedom of 15 , it was indicated that the value of $t-S t a t$. is 4.594 . The value was higher than t-Crit. in which the t-Crit. is 2.131. It could be affirmed that there was a significant difference between the posttest scores in control class. In other word, the mean of posttest score was higher than the mean of pretest score.

\section{Comparative analysis of pretest score of experimental and control class}

The hypothesis testing was carried out to figure out if there is a significant difference involving the pretest score of the experimental class and the control class. The hypotheses are as follow:

$$
\mathrm{H}_{0}: \mu 1=\mu 2
$$

There is no significant difference involving the mean of pretest scores between the experimental and control class.

$$
\mathrm{H}_{\mathrm{i}} \quad: \mu 1 \neq \mu 2
$$

The mean of pretest score of the two classes is significantly different. The two hypotheses above were analyzed by using testing-t: t-Test of Independent Samples of Means. The criteria applied in this section are:

$\mathrm{H}_{0}:$ Accepted if t-Stat $<\mathrm{t}$-Crit. $: \mu 1=\mu 2$

$\mathrm{H}_{0}:$ Rejected if $\mathrm{t}-$ Stat $\geq \mathrm{t}$-Crit. $: \mu 1=\mu 2$

Based on the statistical calculation with the level significance of 0.05 and the degree of freedom of 30 , it was indicated that the value of $\mathrm{t}$-stat was .190 and the value of $\mathrm{t}$ Crit. was 2.042. The value of t-Stat. was lower than the value of $\mathrm{t}$-Crit. It signified that there was no significant difference involving the mean of pretest scores in both experimental and control class.

4. Comparative analysis of the posttest scores of experimental and control class

The hypothesis testing in this part was displayed to find if there is significant difference between the posttest score of the experimental class and the posttest score of the control class.

$$
\mathrm{H}_{0}: \mu 1=\mu 2
$$

There is no significant difference involving the mean of posttest scores from both the experimental and control class. In a similar way to the previous analysis, $t$-Test of Independent Samples of Mean was used. The criteria that were used are as follow: 
$\mathrm{H}_{0}:$ Accepted if t-Stat $<\mathrm{t}$-Crit. $: \mu 1=\mu 2$

$\mathrm{H}_{0} \quad:$ Rejected if $\mathrm{t}-\mathrm{Stat} \geq \mathrm{t}$-Crit. $: \mu 1>\mu 2$

After taking a look at the calculation on the level of significance of 0.05 and the degree of freedom 30, it was discovered that the value of t-Stat. is 3.218; meanwhile the value of t-Crit. was 2.042 . The finding confirmed that the value of t-Stat. was higher than t-Crit. Therefore, it could be signified that there was a significant difference between the posttest score of the experimental class and the posttest of the control class. Hence, the implementation of authentic materials had a significant effect to the achievement of the experimental students.

\section{Data from students' pretest and protest scores}

The outcome scores from the two classes were pretest and posttest. The pretest was carried out to identify the students' initial ability in writing skill and it was given in the first meeting. The test material was the profile of the students' best friend. The pretest scores were to identify the initial skill of the students before the experimental and control group got the treatment. Meanwhile, the posttest was conducted equally to the pretest. It was applied to determine how successful the treatment of using authentic materials in improving students' descriptive writing. The posttest was similar to the pretest and its scores were employed on the purpose of comparing the obtained scores. The scoring system in both pretest and posttest grounded on the aspects proposed by Heaton (1988). The aspects that counted into writing assessment were grammar, mechanism, vocabulary, and content. The comparison of the outcome scores from both experimental and control classes were intended to spot the cause of the treatment conducted in the experimental class. To figure out a significant difference between the scores gained by both classes, the statistical technique of t-test was used.

The pretest scores had gone through normality test. The tool that was used to examine the data was Kolmogorov-Smirnov. The outcome showed that the value of absolute $\mathrm{D}$ is .125 which is lower than the $\mathrm{D}$ table, whereas the value of $\mathrm{D}$ table is .2668. Therefore, it can be concluded that the data above is normal in terms of distribution.

The lowest score of pretest gained by the experiment class was 27 , and the highest score was 73 . There were two students who got score range from $0-30(12.5 \%)$. There were ten students who got score range from 31-60 (62.5\%), and four students got score range from $61-90$ (25\%). Meanwhile, the lowest score of pretest obtained by the control class was 25 and the highest was 75 . The students who got the score range from 0-30 were two students, ten students got score range within 31-60 (62.5\%), and range score from 61-90 were four students (25\%).

The treatment of teaching using authentic materials was conducted a week after the pretest in the experimental class; while teaching descriptive writing using nonauthentic materials was implemented in the control class. After all materials had been delivered, the post-test was awarded to figure out the outcome of using authentic materials in improving students' descriptive writing through collaborative work. The post-test was awarded to both classes.

Based on the data from the posttest, it indicated that the lowest score of the posttest obtained by the experimental class is 55 and the highest score is 87 . There is no students who obtained score range from 0-30, but there were three students acquired score range from $31-60(18.75 \%)$, and there were thirteen students who got score range from 61-90 $(83 \%)$.

Meanwhile, the lowest posttest score obtained by the control class is 36 and the highest score is 82 . None of the students got range score from 0-30. However, there were ten students who obtained range score from 31-60 (62\%), and there were six students who got range score from $61-90$ (38.4\%).

\section{Students' attitudes towards the use of authentic materials}

Having observed the questionnaire data in terms of students' attitudes towards the use of authentic materials in descriptive paragraph, it had been stated that the questionnaire was 
given to sixteen students of experimental class.

There were ten items in the questionnaire in which each item consists of five optional choices, namely strongly disagree, disagree, neither agree nor disagree, agree, and strongly agree. The maximum score for each item is five. For all positive statements, the score is one point for strongly disagree, two points for disagree, three points for neutral, four points for agree, and five points for strongly agree. Whereas for negative statements, the score arrangement is the opposite of positive statements, the score is five point for strongly disagree, four points for disagree, three points for neutral, two points for agree and one point for strongly agree.

The questionnaire items were about the students' attitudes related to the authentic materials that had been used in the classroom. In order to calculate the general data from the questionnaires, the researcher used class interval and range as can be seen in the following table.

\begin{tabular}{|c|c|c|}
\hline No & $\begin{array}{c}\text { Class Interval } \\
\text { (Questionnaire Score) }\end{array}$ & Description \\
\hline 1 & $160-288$ & Strongly Disagree \\
\hline 2 & $289-417$ & Disagree \\
\hline 3 & $418-546$ & Neither agree nor disagree \\
\hline 4 & $547-675$ & Agree \\
\hline 5 & $676-804$ & Strongly agree \\
\hline
\end{tabular}

After calculating the score of the questionnaire from sixteen students, it was found that the total score of the questionnaires was six hundred and fifty four. Having observed the table of class interval above, it was indicated that the students are in agree level. It could be rephrased that the students were fond of learning descriptive writing through authentic materials because it could help them get the ideas to write easily.

In addition, the students attitudes obtained from open-ended questions in the questionnaire reveal that they have positive attitudes. First, the respondents' attitudes to the teaching descriptive writing by using the articles from the internet, magazine and newspaper were very good since these materials can help them in terms of finding the idea, understanding how to write, getting much information in writing, and increasing vocabulary. Furthermore, they stated that learning by using articles from the magazine, newspaper and the internet encouraged them to write actively since the materials applied were interesting. This output was also in coherence with Shrum and Glisan (2000, p. 133) who stated that authentic materials provide an effective means for presenting real language, integrating culture, and heightening comprehension. Based on the respondents' answers, they were categorized into two parts. The description can be seen in the following table.

Table 4. Teaching writing by using article from magazine, newspaper and internet

\begin{tabular}{clcc}
\hline No & \multicolumn{1}{c}{ Respondents' Attitude } & $\begin{array}{c}\text { Number of } \\
\text { Participants }\end{array}$ & Percentage \\
\hline 1 & Authentic material is helpful & 13 & $81.25 \%$ \\
\hline 2 & Authentic materials encourage the learners to write & 3 & $18.25 \%$ \\
\hline
\end{tabular}

Second, the respondents' statement to the improvement of writing after using the articles from magazine, newspaper and internet has also two categories. Fourteen respondents $(87 \%)$ stated that their writings improved after applying the authentic materials. The participants also expressed that they had good progress in descriptive writing, know how to compose sentences and increase their vocabulary after using these authentic materials. While 2 of them (13\%) stated that they do not have any significant progress in their writing yet since they are lack of vocabulary, grammar and ideas to be 
expressed, but they know what to be written and they will try to improve their writing. In this case, they regard that the use of authentic materials in teaching writing should be adopted by teacher, particularly writing description. The following is the description of questionnaire data in accordance with articles from the magazine, internet, and newspaper.

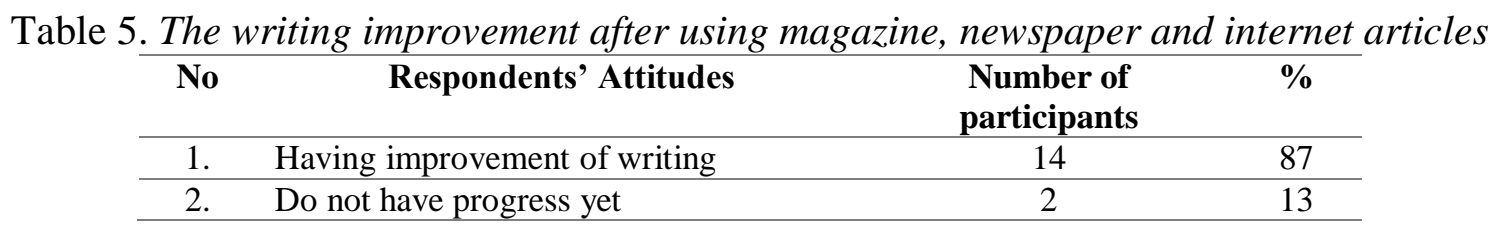

Third concerning respondents' attitudes toward collaborative writing, as many as fourteen students $(87 \%)$ stated that the implementation of collaborative work in descriptive writing is helpful since the collaborative writing can help them develop their writing in terms of organizing the ideas and using the grammar or vocabulary accurately. Furthermore, the collaborative way can encourage them in expressing their idea in writing and improve their writing due to the revision or correction from the collaborators. While the other $13 \%$ or two participants thought that writing together was too noisy for them because their friends kept asking them questions so they preferred to work on their own.

\section{CONCLUSION}

To conclude, learners' writing are improved in terms of organization. It increases in terms of organizing the sentences or paragraphs and using appropriate topic. The learners, furthermore, improve on the use of appropriate grammar or vocabulary such as the use of simple present in writing description, the use of subject verbs agreement, and adjective words or phrases. Then, they also have improvement in content aspects in terms of appropriateness between content and theme, and stylistic technique, i.e. using clear syntax. Based on the result obtained, it can be further said that using authentic materials in descriptive writing is useful. In other words, the implementation of authentic materials in descriptive writing is effective to the improvement of the students' writing skill.

Considering the students' attitude towards the use of authentic materials in descriptive writing, based on the data from the questionnaires, it showed that the students gave positive attitude towards the use of authentic materials in descriptive writing. They felt that the materials assist them in writing, they get many ideas to write and it enhance their vocabulary as well, as a result, they were more interested in writing. In addition, the students were likely to utilize visual and interpersonal styles in learning since they were fond of learning writing descriptive paragraph by using the visual materials, such as articles from magazine, newspaper as well as articles from the internet with their friends in the groups.

However, the challenging and the difficulty of writing a passage seem to be inevitable for most of students. Therefore, teachers should carry out the writing process to the students in order to help them make a passage, such as helping them in determining the topic, brainstorming, generating ideas, first draft writing, editing or revising, and final draft writing. Second, it is very helpful to apply collaborative writing because it has some advantages to the learners' progress such as establishing cooperation and tolerance to one's opinion, facilitating them to modify or adjust their writing, while the downside of using collaborative writing are such as some of the students talked about something that was out of topic with their groups and for introvert students, they looked very uncomfortable working with other students in a group. To minimize these burdens, teacher should observe closely around the students' group to make sure the writing process are not misleading.

\section{REFERENCES}




\section{Gusti Panji Sundana}

The use of authentic material in teaching writing descriptive text

Alwasilah, C. (2000). Perspektif pendidikan bahasa Inggris di Indonesia dalam konteks persaingan global. Bandung: Andira.

Alwasilah, C. (2007). Language, culture and education: A portrait of contemporary Indonesia. Bandung: Andira.

Berardo, S. A. (2006). The use of authentic materials in the teaching of reading. The Reading Matrix Online Journal, 6(2), 60-69.

Feez, S., \& Joyce, H. (2000). Creative writing skills: Literary and media text types. Sydney Phoenix Education.

Gibbons, P. (2002). Scaffolding language scaffolding learning: Teaching second language learners in the mainstream classroom. Portsmouth: Heinemann.

Gilmore, A. (2007). Authentic materials and authenticity in foreign language learning. Retrieved from:
http://journals.cambridge.org/action/displayFullte xt type $=1 \&$ fid $=902976 \&$ jid $=$ LTA\&volumeId $=40$ \&IssueID=02\&aid $=902972 \&$ bodyId $=\&$ membersh ipNumber $=\&$ societyETOCSession $=$

Heaton, J. B. (1988). Writing English language tests. New York: Longman Inc.

Katilie, N. (2003). Improving students' ability by using scaffolding strategy in the process of writing at STP Negeri 3 Tolitoli. (Unpublished Thesis). State University of Malang, Malang, Indonesia.

Rojas, Y. (2012). Authentic task to enhance descriptive paragraph in writing. Unpublished Thesis. Universidad de La Sabana, Bogota, Colombia.

Yusuf, F. N., \& Tanti, D. (2010). Authentic materials in a vocational school writing class: Any advantage?. Proceedings of the 1st UPI International Conference on Technical and Vocational Education and Training. Retrieved from http://fptk.upi.edu/tvet-conference/download. 